\title{
Effect of omeprazole on intragastric bacterial counts, nitrates, nitrites, and $\mathrm{N}$-nitroso compounds
}

\author{
E Verdu, F Viani, D Armstrong, R Fraser, H H Siegrist, B Pignatelli, J-P Idström, \\ C Cederberg, A L Blum, M Fried
}

\begin{abstract}
Previous studies have suggested that profound inhibition of gastric acid secretion may increase exposure to potentially carcinogenic $\mathbf{N}$-nitroso compounds. The aim of this study was to find out if the proton pump inhibitor omeprazole ( $20 \mathrm{mg}$ daily) is associated with increased concentrations of potentially carcinogenic $\mathbf{N}$-nitroso compounds in gastric juice. The volume of gastric contents, number of bacteria, and concentrations of nitrates, nitrites, and $\mathbf{N}$-nitroso compounds was determined in gastric aspirates obtained after an overnight fast in 14 healthy volunteers (7M:7F) after one week of treatment with placebo, and one and two weeks' treatment with omeprazole. Median bacterial concentrations were $1.0 \times 10^{4}$ (range $5.0 \times 10^{3}-5.0 \times 10^{6}$ ) colony forming units (CFU)/ml after one weeks' treatment with placebo and increased significantly to $4.0 \times 10^{5}\left(0-3.3 \times 10^{7}\right) \mathrm{CFU} / \mathrm{ml}$ after two weeks' treatment with omeprazole $(p<0.05)$. A similar increase was seen in the concentration of nitrate reducing bacteria. There was no difference in the volume of gastric aspirates after treatment with omeprazole when compared with placebo $(65(29-155) \mathrm{ml} v 42(19-194) \mathrm{ml})$. The concentration of $\mathbf{N}$-nitroso compounds was $0.13(0-1.0) \mu \mathrm{mol} / \mathrm{l}$ after two weeks of omeprazole, which was not significantly different from that seen with placebo $(0 \cdot 15(0-0.61)$ $\mu \mathrm{mol} / \mathrm{l})$. There was also no increase in the concentrations of nitrates or nitrites. It is concluded that omeprazole ( $20 \mathrm{mg}$ once daily) for two weeks in healthy volunteers is associated with gastric bacterial proliferation but does not increase concentrations of $\mathbf{N}$-nitroso compounds.
\end{abstract}

(Gut 1994; 35: 455-460)

Omeprazole has been established as an effective treatment for peptic ulceration and reflux oesophagitis, for periods of up to five years. ${ }^{15}$ There are still concerns regarding the possible risks of prolonged gastric acid suppression. ${ }^{6-9}$ Prominent among these are uncertainties of adverse effects consequent on bacterial proliferation and colonisation of the upper gastrointestinal tract. Decreased gastric acidity because of age, antacids, ${ }^{11-13} \mathrm{H}_{2}$ receptor antagonists, ${ }^{11} 14$ is and gastric surgery ${ }^{16}$ has previously been reported to increase gastric bacterial colonisation and this has been proposed to increase the formation of potentially carcinogenic $\mathrm{N}$-nitroso compounds. ${ }^{17-20}$

A single study has reported that in healthy subjects, 14 days' treatment with $30 \mathrm{mg}$ omeprazole once daily leads to an increase in the number of bacteria present in the stomach including nitrate reducing bacteria. ${ }^{19}$ As gastric volumes were not assessed, however, it has been suggested that this may have represented an increase in bacterial concentration attributable to a decrease in gastric secretion and, hence, overall gastric volume rather than a true increase in bacterial load - that is, the total number of bacteria. ${ }^{21}$ In addition, samples of gastric juice were obtained through a nasogastric tube that had remained in situ for 10 hours, with the attendant problems of possible contamination. Furthermore, the method used to assess $\mathrm{N}$ nitroso compounds in this study has been shown to be inadequate for the determination of total $\mathrm{N}$ nitroso compounds. ${ }^{22} 23$

We have therefore assessed the influence of 14 days' treatment of omeprazole, $20 \mathrm{mg}$ daily, on total gastric bacteria as well as nitrate reducing bacterial counts by gastric juice aspiration, and measured residual gastric volumes to determine the total number of these organisms in the stomach. To avoid the problems inherent in obtaining bacteriological samples with a nasogastric tube, a novel sampling technique was used to obtain uncontaminated gastric samples. ${ }^{24}$ Finally, both the concentration and total gastric content of N-nitroso compounds (NOC) and their precursors, nitrates and nitrites were measured using a modified extraction procedure to maximise the retrieval of $\mathrm{N}$-nitroso compounds.

\section{Subjects and methods}

\section{SUBJECTS}

Studies were performed in 14 healthy volunteers (seven men, seven women), mean age 24 (range 20 to 46 years), who had no previous history of gastrointestinal disease. Subjects were not permitted any treatment apart from oral contraceptives and paracetamol as necessary. Smoking was not prohibited during the study, but subjects were instructed to maintain their usual smoking habits. Helicobacter pylori infection was excluded in all subjects by a negative ${ }^{13} \mathrm{C}$-urea breath test. ${ }^{25}$

Written informed consent was obtained from all volunteers, and the study was approved by the local ethics committee of the CHUV/PMU, Lausanne.

\section{METHODS}

\section{Study plan}

Treatment was given according to a single blind protocol. Each subject received an initial one week treatment with placebo, followed by 
omeprazole, $20 \mathrm{mg}$ daily for 14 days. Gastric aspirates were obtained after one week of treatment with placebo, and after one and two weeks' treatment with omeprazole.

\section{Gastric aspirations}

After an overnight fast, 24 hours after the last intake of placebo or omeprazole, a nasogastric tube (16 Fr Levine, Argyle, Tullamore, Ireland) covered by silicone tubing, was introduced through an anaesthetised nostril; the position of the tip, $10 \mathrm{~cm}$ distal to the cardia, was verified fluoroscopically. A double sheathed tube (Bacteriocath-Mauch, Munchenstein, Switzerland) - consisting of an outer tube, capped at the distal end, and containing an inner sterile catheter - was passed into the stomach through the previously inserted nasogastric tube. The distal cap was then dislodged and samples of gastric contents aspirated through the inner catheter.

\section{Bacteriological assays}

One $\mathrm{ml}$ of the aspirate was placed in an anaerobic transport medium (Port-A-Germ, Biomérieux, France) and plated within three hours onto aerobic and anaerobic culture media. The samples were serially diluted with phosphate buffer containing $1 \%$ peptone. Aerobic cultures were performed by plating samples on the following media: (a) 5\% sheep blood agar; (b) MacConkey agar; (c) phenylethyl alcohol agar; (d) Sabouraud glucose agar containing gentamicin and chloramphenicol.

Anaerobic cultures were performed by inoculating the following solid media: (a) blood agar containing 5\% sheep blood supplemented with cysteine and vitamin $\mathrm{K}_{1}$; (b) neomycin agar; (c) vancomycin/nalidixic acid agar.

Media were incubated for a minimum of 72 hours with a first reading at 24 hours for aerobic growth and 48 hours for anaerobes. Bacteria were identified by standard methods ${ }^{26}$ to species level or, where appropriate, to genus level only. Bacterial numbers were determined by a colony count of the individual bacterial morphologies and expressed logarithmically as colonies/ml.

\section{Nitrate, nitrite, and NOC assays}

For the nitrate and nitrite assays, $0.6 \mathrm{ml}$ of gastric juice was added to a tube containing $0 \cdot 2$ $\mathrm{ml}$ of $\mathrm{NaOH} 0.5 \mathrm{~N}$. The $\mathrm{NOC}$ assays were performed on a further $2.5 \mathrm{ml}$ of gastric juice, which was placed in a Pyrex/Teflon joint stoppered vial containing $50 \mathrm{mg}$ of solid sulphamic acid, kept at room temperature with protection from light for a further four minutes and then stored in the dark at $-20^{\circ} \mathrm{C}$ until analysis within eight days. Nitrite was determined colorimetrically by diazotisation of sulphanilic acid followed by coupling to $\mathrm{N}$-(1-napthyl)-ethylenediamine after removal of interfering substances on an anion exchange column. Nitrate was analysed by the same method after reduction to nitrite on a cadmium column. ${ }^{27}$ NOC concentrations were determined using a previously described tech- nique. ${ }^{28}$ Briefly the gastric juice sample was injected directly into refluxing ethyl acetate, containing either acetic acid $-0 \cdot 1 \%$ ( $\mathrm{vol} / \mathrm{vol}$ ) $\mathrm{HCl}$ for determining thermo and acetic acid labile thermal energy analyser responsive compounds (TAC) or hydrogen bromide for the determination of TAC plus NOC. The amount of nitric oxide released in each case was measured through chemoluminescence detection using a thermal energy analyser, with the difference between the two determinations representing the concentration of total NOC in the sample. The limit of detection was $0.01 \mu \mathrm{mol} / 1$.

\section{pH measurements}

Immediately after aspiration, the $\mathrm{pH}$ of aspirates was determined using a combined glass electrode (M3-440, Ingold Messtechnik AG, Urdorf, Switzerland) and a precalibrated $\mathrm{pH}$ meter (Radiometer pHM 75, Radiometer, Copenhagen, Denmark).

\section{Residual gastric volume}

After aspiration of the gastric samples for determination of bacterial counts, and concentrations of nitrate, nitrite, and NOC, $50 \mathrm{ml}$ of polyethylene glycol solution 4000 (PEG) was instilled through the nasogastric tube; the subject then moved around on the examination couch over a five minute period to permit thorough mixing of gastric contents. The stomach was then aspirated to dryness; the volume of aspirate was noted and two $1 \mathrm{ml}$ aliquots were stored at $-20^{\circ} \mathrm{C}$ for subsequent measurement of PEG concentration by turbidimetry ${ }^{28}$ to permit evaluation of the residual gastric volume before insertion of nasogastric tube.

\section{Evaluation of results and statistical analysis}

Statistical evaluation of paired data was performed using the Wilcoxon's signed rank test. ${ }^{29}$ The Spearman rank correlation coefficient test was used to test the relation between $\mathrm{pH}$ values and bacterial counts, and concentrations of NOC and nitrite. The difference between bacterial counts, nitrites, and $\mathrm{NOC}$ at $\mathrm{pH}$ values above and below 4 were compared with the MannWhitney U test.

Bacterial, nitrate, nitrite, and NOC contents were calculated by multiplying and concentrations by the calculated residual gastric volume. All data are presented as medians (range).

\section{Results}

Fourteen subjects completed the study. One subject withdrew from the study after the first week for reasons unconnected with the experiment and was replaced according to protocol. Epigastric pain was reported by one subject two days after starting omeprazole and diarrhoea was reported by another during treatment with placebo. Both subjects completed the study and no other adverse events were noted. 
TABLE I Types of bacteria cultured from gastric aspirates

\begin{tabular}{|c|c|c|c|}
\hline Bacterium & Placebo & Omeprazole I week & Omeprazole 2 weeks \\
\hline Non-haemolytic Streptococcus ${ }^{\star}$ & $7(2)$ & $10(5)$ & $8(7)$ \\
\hline$\alpha$ Haemolytic Streptococcus ${ }^{\star}$ & $6(0)$ & $9(7)$ & $9(6)$ \\
\hline B Haemolytic Streptococcus ${ }^{\star}$ & - & & $1(1)$ \\
\hline$S$ epidermidis ${ }^{\star}$ & - & $2(1)$ & l(1) \\
\hline$S$ aureus $\star$ & - & $-(6)$ & $1(0)$ \\
\hline Neisseria spp $p^{\star}$ & $2(2)$ & $6(0)$ & $9(8)$ \\
\hline Lactobacillus spp $p^{\star}$ & $4(1)$ & $1(3)$ & - \\
\hline Corynebacterium spp* & $2(2)$ & 4 & $8(6)$ \\
\hline Stomatococcus sp & - & - & $1(1)$ \\
\hline Candida albicans & $3(0)$ & $3(0)$ & $2(0)$ \\
\hline Candida sp & $1(0)$ & - & - \\
\hline Fusobacterium spp ${ }^{\star}$ & - & - & $3(2)$ \\
\hline Peptostreptococcus sp & _- & $1(1)$ & $1(1)$ \\
\hline Bacteroides gr fragilis & - & $3(3)$ & $4(4)$ \\
\hline Bacteroides non gr fragilis & - & $1(1)$ & - \\
\hline Bacteroides melaninogemicus & - & $3(1)$ & $2(2)$ \\
\hline Bacteroides sp & - & $1(1)$ & - \\
\hline Enterobactr cloacae & - & $1(0)$ & $1(1)$ \\
\hline$E$ coli & $1(0)$ & - & - \\
\hline
\end{tabular}

Bacterial species during placebo and omeprazole, showing the total number of subjects from whom the bacteria was cultured and the number of subjects with bactrial counts $>10^{5} \mathrm{CFU} / \mathrm{ml}$ (in brackets) after treatment with placebo and omeprazole. Nitrate reducing bacteria are shown by *.

\section{CHARACTERISTICS OF GASTRIC JUICE}

Gastric sample $p H$

The median $\mathrm{pH}$ of the samples was $1.9(1 \cdot 3-5 \cdot 8)$ during treatment with placebo, $3.9(1 \cdot 9-6 \cdot 4)$ after one weeks' treatment with omeprazole, and $4 \cdot 3(1 \cdot 3-6 \cdot 8)$ after two weeks' treatment with omeprazole. At weeks 1, 2, and 3, sample pH was greater than 4 , in 2,7 , and 8 volunteers respectively.

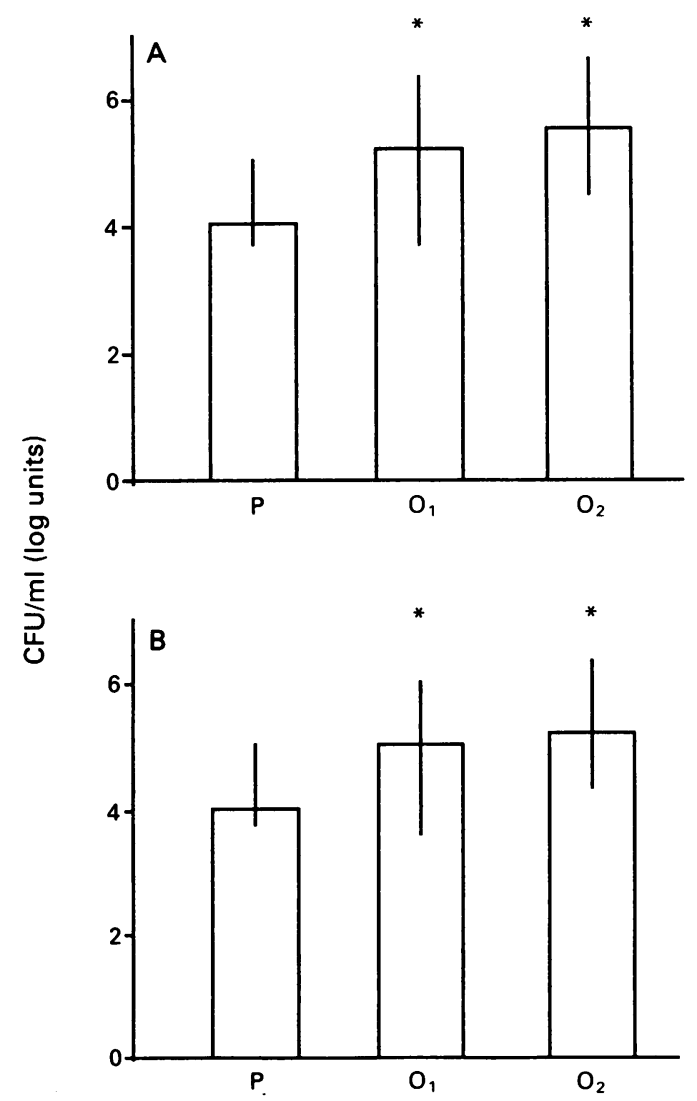

Figure 1: Concentration of $(A)$ total bacteria, and $(B)$ nitrate reducing bacteria after one week of placebo $(P)$ and treatment with omeprazole for one $\left(O_{1}\right)$ and two $\left(O_{2}\right)$ weeks. There was a significant increase in the concentrations of total and nitrate reducing bacteria after both one and two weeks of omeprazole treatment when compared with placebo, but no significant difference between the concentrations after one and two weeks of omeprazole. (Values are logarithms of colony forming units $(C F U) / m l$ expressed as median and interquartile range, ${ }^{\star} p<0.05$.)
Gastric volume

The median fasting gastric volume was $41.5 \mathrm{ml}$ (19-193.7) during placebo treatment. There were no significant changes in the median gastric volumes after either one or two weeks of omeprazole treatment: $41.5 \mathrm{ml}(21 \cdot 9-137 \cdot 7)$ and $64 \cdot 9 \mathrm{ml}(28 \cdot 6-154 \cdot 9)$ respectively.

\section{BACTERIOLOGY}

Table I lists the bacterial species found in gastric juice during treatment with placebo and after omeprazole. There was a significant increase in the total bacterial concentration after one $(p<0.05)$ and two weeks $(p<0.05)$ of omeprazole without a significant difference between the first and second treatment week of omeprazole (Fig 1). The total number of bacteria in gastric juice also increased significantly after one and two weeks of omeprazole ( $\mathrm{p}<0.05 v$ placebo), but there was no significant difference between the first and second week of omeprazole (Fig 2).

There was a significant increase in the concentration of nitrate reducing bacteria after one and two weeks of omeprazole $(\mathrm{p}<0.05 v$ placebo) without a significant difference between the first and second week of omeprazole (Fig 1). The total number of nitrate reducing bacteria in gastric juice also increased after one and two weeks of omeprazole $(\mathrm{p}<0.05 v$ placebo $)$ without a
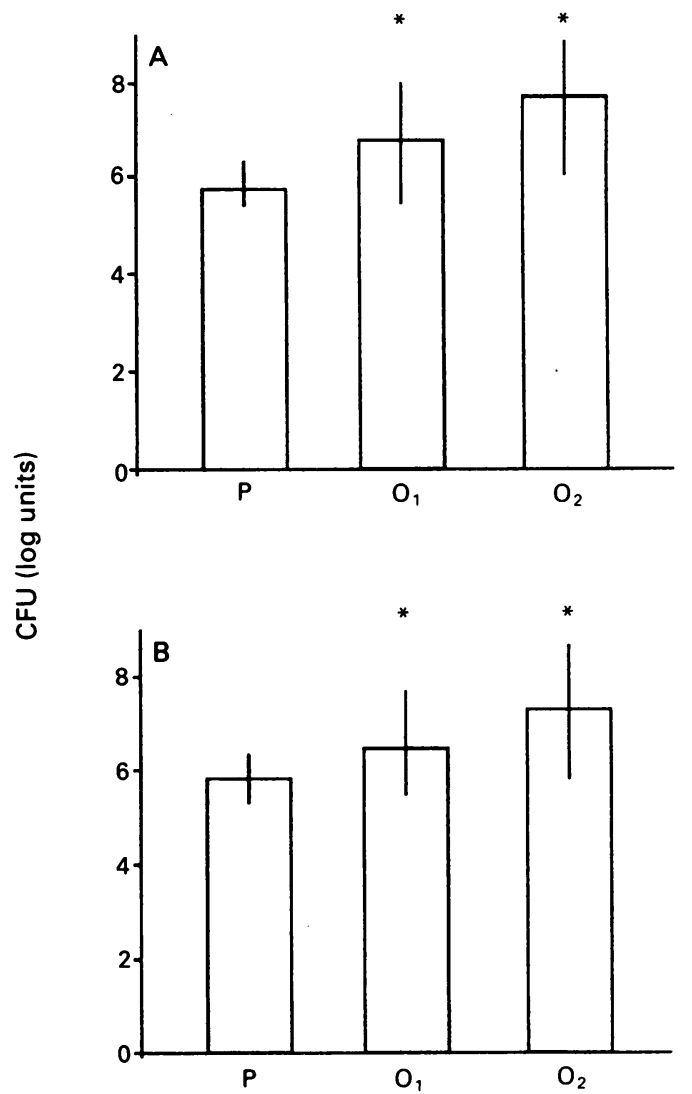

Figure 2: Total bacterial numbers for $(A)$ all bacteria, and $(B)$ nitrate reducing bacteria after one week of placebo $(P)$ and treatment with omeprazole for one $\left(\mathrm{O}_{1}\right)$ and two $\left(\mathrm{O}_{2}\right)$ weeks.

There was a significant increase in the numbers of total and nitrate reducing bacteria after both one and two weeks of omeprazole treatment when compared with placebo, but no significant difference between the total number of bacteria after one and two weeks of omeprazole. (Values are logarithms of colony forming units $(C F U) / m l$ expressed as median and interquartile range, ${ }^{\star} p<0.05$. 
Figure 3: Concentration ( $\mu \mathrm{mol} / \mathrm{ml}$ ) of nitrate, nitrite, and $N$-nitroso compounds (NOC) in gastric juice after placebo $(P)$, one week $\left(O_{1}\right)$, and two weeks $\left(\mathrm{O}_{2}\right)$ of omeprazole. There was no significant difference between treatment weeks for any parameter. (Individual values for each subject. Horizontal bars show medians.)

Figure 4: Total content ( $\mu \mathrm{mol})$ of nitrate, nitrite, and $N$-nitroso compounds (NOC) in gastric juice after placebo $(P)$, one week $\left(\mathrm{O}_{2}\right)$, and two weeks $\left(\mathrm{O}_{2}\right)$ of omeprazole. There was no significant difference between treatment weeks for any parameter. (Individual values for each subject.

Horizontal bars show medians.)
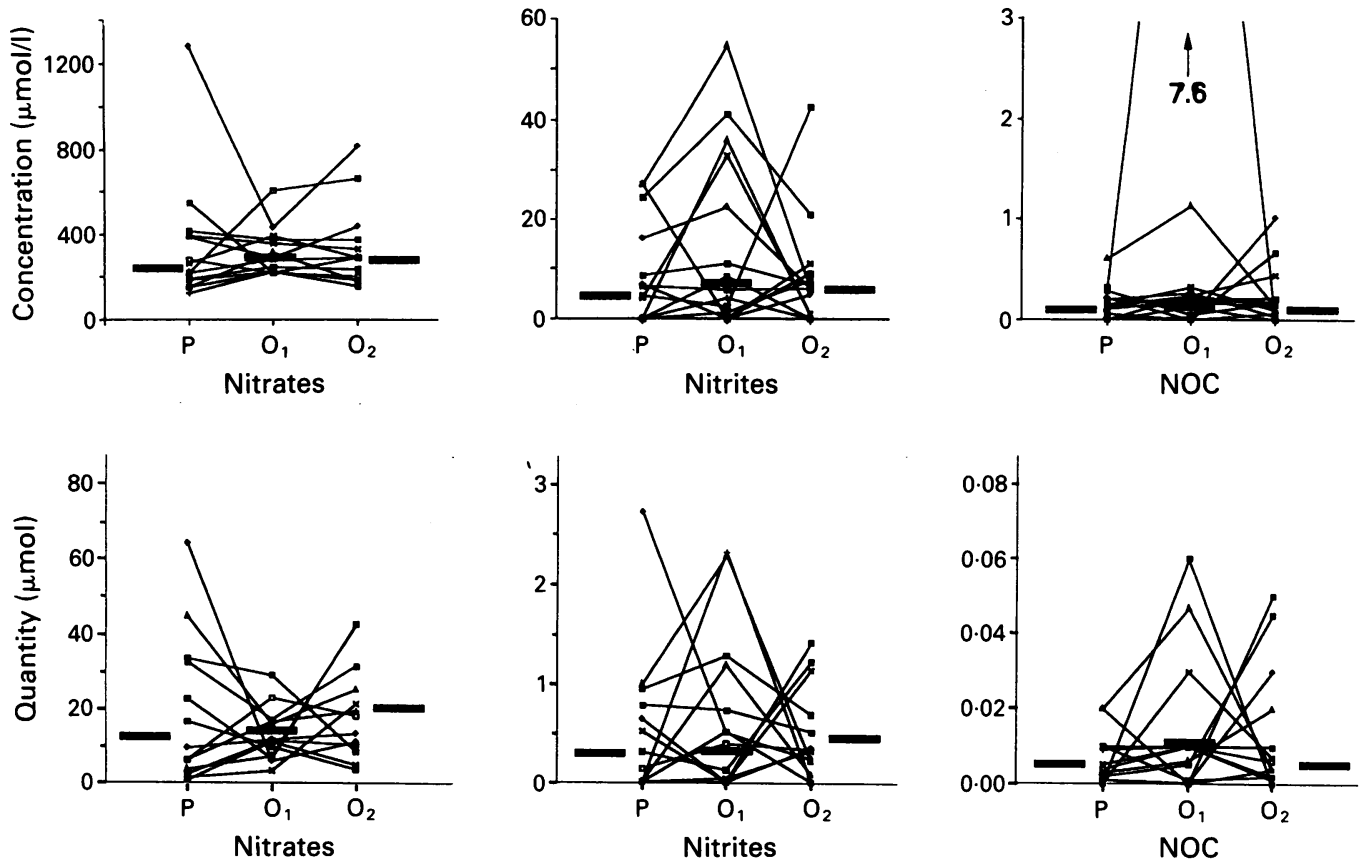

significant difference between the first and second weeks of omeprazole (Fig 2).

NITRATES, NITRITES, AND N-NITROSO COMPOUNDS (NOC)

\section{Nitrates}

The median nitrate concentrations were not significantly different during treatment with placebo, when compared with those after one, and two weeks' treatment with omeprazole (Fig 3). Similarly, the total amount of nitrates (median) was not significantly different after placebo treatment, when compared with the values after one and two weeks' treatment with omeprazole, respectively (Fig 4). There was similarly no significant difference either in the nitrate concentrations or total nitrate contents between placebo and the first and second weeks' treatment with omeprazole $(p>0 \cdot 05)$.

\section{Nitrites}

Nitrite concentrations during treatment with placebo were not significantly different from those after one and two weeks' treatment with omeprazole (Fig 3). Total nitrite content did not change after one and two weeks' treatment with omeprazole when compared with placebo (Fig 4).

\section{$N$-nitroso compounds (NOC)}

There was no significant difference in the con- centrations of NOC after one and two weeks' treatment with omeprazole compared with placebo (Fig 3). There was also no significant difference in the total NOC contents after one and two weeks' treatment with omeprazole compared with placebo (Fig 4).

RELATION BETWEEN PH, BACTERIAL COUNTS, NITRATES, NITRITES, AND N-NITROSO COMPOUNDS Total bacterial concentrations and nitrate reducing bacteria concentrations were significantly higher when aspirate $\mathrm{pH}$ was $>4$ (Table II, $p<0.05)$. No significant relation was found between $\mathrm{pH}$ values and nitrates, nitrites, or NOC concentrations or the total amount of these compounds.

\section{Discussion}

The results of this study show that omeprazole, $20 \mathrm{mg}$ daily is associated with an increase in the gastric concentration and total number of bacteria, including nitrate reducing bacteria. There was, however, no increase in the concentrations or total contents of nitrites or NOC for the group as a whole although transiently raised concentrations were noted in several subjects. It is well established that reduced gastric acidity leads to increased bactrial proliferation in the gastrointestinal tract, ${ }^{11} 1{ }^{1416}$ and there has been a debate whether this may lead to increased formation of NOC, some of which are known to be carcinogenic in animals. ${ }^{13}{ }^{30-33}$ In patients who have had gastric surgery more than 20 years

TABLE II Relation between $\mathrm{pH}$ and concentrations of bacteria (total and nitrate reducing), nitrites, and $N$-nitroso compounds (NOC)

\begin{tabular}{lllr}
\hline & $p H<4(n=25)$ & $p H>4(n=17)$ & $p$ Value \\
\hline Total bacteria $(\mathrm{CFU} / \mathrm{ml})$ & $<1 \cdot 0 \times 10^{4}\left(<1 \cdot 0 \times 10^{4}-3 \cdot 3 \times 10^{7}\right)$ & $3 \cdot 1 \times 10^{5}\left(<1 \cdot 0 \times 10^{4}-5-2 \times 10^{7}\right)$ & $<0 \cdot 001$ \\
Nitrate reducing bacteria $(\mathrm{CFU} / \mathrm{ml})$ & $<1 \cdot 0 \times 10^{4}\left(<1.0 \times 10^{4}-2 \times 10^{7}\right)$ & $2 \cdot 0 \times 10^{5}\left(<1.0 \times 10^{4}-3 \cdot 1 \times 10^{7}\right)$ & $<0 \cdot 001$ \\
Nitrite concentration $(\mu \mathrm{mol} / \mathrm{l})$ & $5 \cdot 9(0-35 \cdot 9)$ & $9 \cdot 1(0-54 \cdot 8)$ & $0 \cdot 28$ \\
NOC concentration $(\mu \mathrm{mol} / \mathrm{l})$ & $0 \cdot 18(0-0 \cdot 68)$ & $0 \cdot 18(0-7 \cdot 6)$ & $0 \cdot 448$ \\
\hline
\end{tabular}

Values are shown as medians and range at $\mathrm{pH}$ less than and greater than 4 . The nitrite and NOC concentrations when the aspirate was $>4$ $\mathrm{pH}$ were not significantly different from those when $\mathrm{pH}$ was $<4$ despite a significant increase in both total bacteria and nitrate reducing pH were not significantly different from those when $\mathrm{pH}$ was $<4$ despite a signi
bacteria when aspirate $\mathrm{pH}$ was $>4(\mathrm{p}<0.001)$. CFU $=$ colony forming units. 
previously, an increased incidence of both gastric and other gastrointestinal malignancies, which has been attributed to NOC has been reported. ${ }^{34-37}$ The comparative importance, however, of reduced acidity and the type of surgery are not known..$^{38}$ It has been hypothesised that the increase in gastric $\mathrm{pH}$ is the most important factor as it may permit the proliferation of bacteria that can reduce dietary nitrate to nitrite with the subsequent chemical formation of nitrosamines and other NOC from secondary and tertiary amines..$^{18}{ }^{39}$ It needs to be remembered, however, that nitrate reduction can also occur non-enzymatically and this reaction occurs preferentially at a low $\mathrm{pH}$.

In the only previous comparable study, Sharma et al reported that $\mathbf{1 4}$ days of once daily treatment with $30 \mathrm{mg}$ omeprazole, led to a reversible increase in gastric bacterial flora with a consequent increase in nitrite and NOC production, which was reversible when treatment finished. ${ }^{19}$ In this study, the total contents of gastric bacteria, nitrates, nitrites, and NOC were also calculated because it was suggested that the increased concentration seen in the study by Sharma et al may have been an artefact as a result of the decreased volume of gastric secretion produced by omeprazole. ${ }^{21}$ We found no reduction in gastric volume assessed 24 hours after the last omeprazole dose, however, showing that omeprazole had no effect on the secretion volume. There was thus a concordance between the values obtained for both gastric concentrations and content for all parameters.

This study also showed that reduced acid secretion after omeprazole is associated with proliferation of bacteria, including nitrate reducing species but it has not confirmed a subsequent increase in nitrite or NOC production for the group as a whole. The most notable difference between the two studies is that the median bacterial counts reported by Sharma et al were more than 100-fold greater than those seen in this study. As omeprazole produces a dose dependent increase in gastric $\mathrm{pH},{ }^{41}$ the lower bacterial counts in this study could have been a result of differences in intragastric $\mathrm{pH}$ because of the lower dose of omeprazole in the study $(20 \mathrm{mg} v$ $30 \mathrm{mg}$ ). The median $\mathrm{pH}$ in our study after treatment with omeprazole was $4 \cdot 0$, consistent with those previously reported for healthy volunteers, ${ }^{1941} 42$ although higher $\mathrm{pH}$ values have been reported in patients with duodenal ulceration and Helicobacter pylori infection. ${ }^{43-45}$ In the study by Sharma $e t a l$, however, the mean $\mathrm{pH}$ after 14 days of omeprazole was 3.0 and it therefore seems that a different intragastric $\mathrm{pH}$ is probably not responsible for the differences in bacterial counts. It is possible that the overnight intubation technique used to obtain gastric aspirates in the study by Sharma, may have led to inadvertent colonisation of the gastric juice by oropharyngeal organisms. Furthermore, proliferation may have been promoted by the hourly aspiration of gastric contents resulting in a reduction in the pool of gastric acid available to sterilise gastric contents. It is thus possible that the increases in nitrite and N-nitrosamine concentrations reported by Sharma were due to the considerably higher bacterial counts when com- pared with this study in which a sterile sampling technique was applied. The lower nitrite concentrations seen in this study could have been a result of low initial concentrations of nitrate; however, the nitrate concentrations reported here are similar to those reported in other study populations in France, Colombia, and the United Kingdom (Pignatelli, unpublished data). The use of a different NOC extraction procedure probably does not explain the difference in NOC concentrations between the two studies. Previous studies ${ }^{22}$ show that only about $50-60 \%$ of the total NOC are extractable in organic solvents such as ethyl acetate used by Sharma et al. ${ }^{19}$ On this basis, the NOC concentrations reported by Sharma et al during placebo are predictably lower than those found in this study. This is consistent with the mean NOC concentration $(0.09 \mu \mathrm{mol} / \mathrm{l})$ found in the study by Sharma et al before treatment, which is about $55 \%$ of the value seen in our study. Despite the more accurate measurement technique in our study, ${ }^{23}$ no increase in NOC concentrations was seen during omeprazole administration. Thus, the absence of an increase in nitrite and NOC concentrations for the group as a whole seen in our study may be explained by the comparatively small rise in bactrial proliferation.

Despite the lack of an overall effect on nitrite and NOC concentration, transient increases were seen in several subjects. Interestingly the subjects with the highest NOC concentrations were not the same as those with the highest gastric nitrite content. The importance of these transient increases in gastric NOC concentration is unknown, and there was no association between high $\mathrm{pH}$ values and raised NOC concentrations.

In summary this study has shown that treatment with omeprazole $20 \mathrm{mg}$ once daily for two weeks in healthy volunteers increases the degree of bacterial proliferation in a manner that does not increase with time, and does not increase NOC concentrations. Further studies are required, however, before these results can be confidently extrapolated to patients with peptic ulceration and gastritis secondary to Helicobacter pylori infection in whom omeprazole may have a more noticeable effect on gastric acid secretion.

We wish to acknowledge the technical assistance of $\mathrm{Mr} P$ Thuillier, IARC, Lyon, France. Supported by SNF Grant Nos 32-2639.89/32-25727.88 and a grant from Astra Hässle AB, Mölndal, Sweden. Part of this study was presented in abstract form at a symposium 'Nitrosamines and N-Nitroso Compounds: form at a symposium 'Nitrosamines and N-Nitroso Compounds:
Chemistry and Biochemistry' held in Washington in August 1991.

1 Hetzel DJ, Dent J, Reed WD, Narievala FM, Mackinnon M, McCarthy JH, et al. Healing and relapse of severe peptic McCarthy $\mathrm{JH}$, et al. Healing and relapse of severe peptic esophagitis after treatme $1988 ; 95$ : $903-12$.

2 Klinkenberg-Knol EC, Jansen JBMJ, Lamers CBHW, Nelis F, Snel P, Meuwissen SGM. Use of omeprazole in the management of reflux oesophagitis resistant to $\mathrm{H}_{2}$ receptor antagonists. Scand $\mathcal{F}$ Gastroenterol 1989; 24 (suppl 166): 88-93.

3 Brunner G, Creutzfeldt W. Omeprazole in the long-term treatment of patients with acid-related diseases resistant to ranitidine. Scand $\mathcal{f}$ Gastroenterol 1989; 24 (suppl 166): 101-5.

4 Lundell L. Prevention of reflux oesophagitis after endoscopic healing: the efficacy and safety of omeprazole compared with ranitidine. Digestion 1990; 47 (suppl 1): 72-5.

5 Koop H, Arnold R. Long-term maintenance treatment of reflux eosphagitis with omeprazole. Prospective study in patients with $\mathrm{H}_{2}$-blocker-resistant oesophagitis. Dig Dis $\mathrm{Sci}$ patients with $\mathrm{H}_{2}$.

6 Wormsley KG. Assessing the safety of drugs for the long-term treatment of peptic ulcers. Gut 1984; 25 : 1416-23. 
7 Festen HPM. Profound gastric acid inhibition. Advantages and potential hazards. Scand F Gastroenterol 1989; 24 (suppl 171): $99-105$.

8 Stern WR. Summary of the 34th meeting of the food and drug administration gastrointestinal drugs advisory committee March 15 and 16 1989. Am f Gastroenterology 1989; 84: 1351-5.

5 Colin-Jones DG. Acid suppression: how much is needed? Adjust it to suit the condition. $B M F$ 1990; 301: $564-5$.

10 Husebye E, Skar V, Hoverstad T, Melby K. Fasting hypochlorhydria with Gram positive flora is highly prevalent in healthy old people. Gut 1992; 33: 1331-7.

11 Snepar R, Poporad GA, Romano R, Kobasa WD, Kaye D. Effect of cimetidine and antacid on gastric microbial flora. Infect Immun 1982; 36: 518-24.

12 Du Moulin GC, Paterson DG, Hedley-Whyte J, Lisbon J. Aspiration of gastric bacteria in antacid-treated patients: a frequent cause of postoperative colonisation of the airway. Lancet 1982; i: 242-5.

13 Ruddell WSJ, Axon ATR, Findlay JM, Bartholomew BA, Hill MJ. Effect of cimetidine on the gastric bacterial flora. Lancet MJ. Effect of cim

14 Milton-Thompson GJ, Lightfoot NF, Ahmet Z, Hunt RH, Barnard J, Bavin PMG, et al. Intragastric acidity, bacteria, nirite, and $\mathrm{N}$-nitroso compounds before, during, and after cimetidine treatment. L ancet 1982; i: 1091-5.

15 Meyrick Thomas J, Misiewicz JJ, Cook AR, Hill MJ, Smith PLR, Walters CL, et al. Effect of one year's treatment with ranitidine and of truncal vagotomy on gastric contents. Gut 1987; 28: 726-38.

16 Allan Gray JD, Shiner M. Influence of gastric $\mathrm{pH}$ on gastric and jejunal flora. Gut 1967; 8: 574-81.

17 Hall CN, Darkin D, Brimblecombe R, Cook AJ, Kirkham JS, Northfield TC. Evaluation of the nirtosamine hypothesis of gastric carcinogenesis in pecancerous conditions. Gut 1986; 27: 491-8.

18 Northfield TC, Hall CN. Carcinoma of the gastric stump: risks and pathogenesis. Gut 1990; 31: 1217-9.

19 Sharma BK, Santana IA, Wood EC, Walt RP, Peraire M, Noone $\mathrm{P}$, et al. Intragastric bacterial activity and nitrosation before, during and after treatment with omeprazole. $B M \mathcal{F}$ 1984; 289: 717-9.

20 Watt PCH, Sloan JM, Donaldson JD, Patterson CC, Kennedy TL. Relationship between histology and gastric juice $\mathrm{pH}$ and nitrite in the stomach after operation for duodenal ulcer. Gut 1984; 25 : 246-52.

21 Wormsley KG. Intragastric bacterial activity and nitrosation before, during and after treatment with omeprazole [Letter]. BMF 1984; 289: 1007 .

22 Pignatelli B, Malaveille C, Chen CS, Ohshima H, Hautefeuille A, Thuillier P, et al. N-nitroso compounds (NOC), genotoxins and their precursors in gastric juice (GJ) from humans with or without precancerous lesions
of the stomach. In: O'Neill IK, Chen J, Bartsch H, eds. Relevance to human cancer of $N$-nitroso compounds, tobacco smoke and mycotoxins. Lyon: IARC Scientific Publications No 105. International Agency for Research on Cancer, 1991: 172-7.

23 Pignatelli B, Richard I, Bourgade MC, Bartsch H. Improved group determination of total $\mathrm{N}$-nitroso compounds (NOC) in human gastric juice by denitrosation and thermal energy analysis. Analyst 1987; 112: 945-9.

24 Bardhan PK, Gyr K, Beglinger C, Vogtlin J, Frey R, Vischer W. Diagnosis of bacterial overgrowth after culturing proximal small bowel aspirate obtained during routine upper proximaintestinal endoscopy. Scand $\mathcal{f}$ Gastroenterol 1992; 27: 253-6.
25 Rauws EAJ. Detecting Campylobacter pylori with the ${ }^{13} \mathrm{C}$ - and ${ }^{4} \mathrm{C}$-urea breath test. Scand $\mathcal{F}$ Gastroenterol 1989; 24 (suppl 160): 25-6.

26 Balows A, Hausler WJ, Herrmann KL, Isenberg HD, Schandomy H, eds. Manual of clinical microbiology. 5th Ed. Washington DC: American Society of Microbiology, 1991.

27 Green LC, Wagner DA, Glogowski J, Skipper PL, Wishnok JS, Tannenbaum SR. Analysis of nitrate, nitrite and [131-8.

28 Malawer SJ, Powell DW. An improved turbidimetric analysis of polyethylene glycol utilizing an emulsifier. Gastronterology 1967; 53: $250-6$

29 Streithberg B, Rohmel J. Exakte Verteilungen fur Rang- und Randomisierungstests im allgemeinen c-Stichprobenproblem. $E D V$ in Medizin und Biologie 1987; 18: 12-9.

30 Tannenbaum SR. Ni-nitroso compounds: a perspective on human exposure. Lancet 1983; i: 629-31.

31 Reed PI, Smith PLR, Haines K, House FR, Walters CI. Effect of cimetidine on gastric juice N-nitrosamine concenEffect of cimetidine on gastric

32 Lijinsky W. Nitrosamines and nitrosamides in the aetiology of gastrointestinal cancer. Cancer 1977; 40: 2446-9.

33 Reed PI, Smith PLR, Haines K, House FR, Walters CI Gastric juice N-nitrosamines in health and gastroduodenal disease. Lancet 1981; ii: 550-2.

34 Watt PCH, Patterson CC, Kennedy TL. Late mortality after vagotomy and drainage for duodenal ulcer. $B M \mathcal{F} 1984 ; 288$ : 1335-8.

35 Viste A, Bjornestad E, Opheim P, Skarstein A, Thunold J, Hartveit $\mathrm{F}$, et al. Risk of carcinoma following gastric operations for benign disease. A historical cohort study of 3470 patients. Lancet 1986 ; ii: $502-5$.

36 Ross AHM, Smith MA, Anderson JR, Small WP. Late mortality after surgery for peptic ulcer. $N$ Engl $\mathcal{Y}$ Med 1982; 307: 519-22.

37 Caygill CPJ, Hill MJ, Hall CH, Kirkham JS, Northfield TC. Increased risk of cancer at multiple sites after gastric surgery for peptic ulcer. Gut 1987; 28: 924-8.

38 Schlag P, Bockler R, Peter M, Herfarth Ch. Nitrite and Nnitroso compounds in the operated stomach. Scand $\mathcal{F}$ Gastroenterol 1981; 16 (suppl 67): 63-9.

39 Calmels S, Oshima H, Vincent P, Gounot AM, Bartsch $H$ Screening of microorganisms for nitrosation catalysis at $\mathrm{pH}$ 7 and kinetic studies on nitrosamine formation from secondary amines by $\mathrm{E}$ coli strains. Carcinogemesis $1985 ; 6.911-5$.

40 Leach S, Thompson M, Hill M. Bacterially catalysed N nitrosation in the human stomach. Carcinogenesis 1987; 8 . 1907-12.

41 Sharma BK, Walt RP, Pounder RE, Gomes M de FA, Wood EC, et al. Optimal dose of oral omeprazole for maximal 24 hour decrease of intragastric acidity. Gut 1983; 25: 957-64.

42 Bell NJ, Rohss K, Cederberg C, Hunt RH. Does tachyphylaxis and/or rebound acid secretion occur during/after treatment with omeprazole or ranitidine. Gastroenterology 1993; 104: A41.

43 Cederberg C. Clinical pharmacology of intravenous omeprazole. Experimental studies in healthy subjects and duodenal ulcer patients [Thesis]. Goteburg: University of Goteborg, 1992: 1-19.

44 Walt RP, Gomes M de FA, Wood EC, Logan LH, Pounder RE. Effect of oral omeprazole on 24 hour intragastric acidity. $B M \mathcal{F}$ 1983; 287: 12-4.

45 Armstrong D, Verdu E, Fraser R, Viani F, Idström J-P, Cederberg $C$, et al. Helicobacter pylori infection augments the antisecretory effect of omeprazole. [Abstract]. Acta Gastroenterol Belg 1993; 56: 129. 